\title{
PENGARUH KONFLIK KERJA DAN STRES KERJA TERHADAP KINERJA KARYAWAN PADA CV. APOTIK KELUARGA PEKANBARU
}

\author{
Eka Putra \\ Sekolah Tinggi Ilmu Ekonomi Riau \\ E-mail: ekaputra@lecturer..stieriau-akbar.ac.id
}

\begin{abstract}
The purpose of this study was to analyze the effects of work conflict and work stress on employee performance CV. Apotik Keluarga Pekanbaru. This study uses descriptive and quantitative methods with a population and the sample is all employees that totaling 66 people. The average values for all Work Conflict statements and Work Stress variables are 3.00 and 3.02, respectively, which means that these two factors are in the medium class interval. The value of t_count for the work variable conflict t_count> t_table $(-2.196>1,998)$ and the significance of 0,000<0.05, meaning that work conflict has a significant effect on employee performance. A negative sign indicates the higher the level of work conflict, the lower the employee's performance. As for the Work Stress variable $t$ count $<t$ table $(-0.033<1,998)$ and probability $(0.974)>0.05$. So the Work Stress variable partially has no effect and is not significant on Employee Performance. Then from the simultaneous test results obtained that Fcount $>$ Ftable $(22,010>3.14)$ and a probability value of $0,000<0.05$ then the variable Work Conflict and Work Stress simultaneously have a significant effect on Employee Performance CV. CV. Apotik Keluarga Pekanbaru. Based on the Adjusted R Square value obtained at 0.393 on the coefficient of determination test, the effect is $39.3 \%$.
\end{abstract}

Keywords: Work Conflict, Work Stress and Employee Performance

\section{A. PENDAHULUAN}

Perkembangan ilmu pengetahuan dan teknologi yang sangat pesat, akan membawa perubahan dalam kehidupan manusia. Perubahan-perubahan itu membawa akibat yaitu tuntutan yang lebih tingi terhadap setiap individu untuk lebih meningkatkan Kualitas dan kapabilitas diri agar bisa mengikuti maju perkembangan sosial ekonomi di tengah masyarakat luas.

Pesatnya perkembangan ilmu teknologi dan sosial ekonomi masyarakat menimbulkan pola hidup yang sangat kempetitif. Sehingga tak jarang terjadi pergesekan ide dan konflik kepentingan maka adakalanya bagi individu yang kurang dapat menyesuaikan diri dengan perkembangan tersebut akan mengalami stress kerja selanjutnya akan mengganggu kinerja karyawan dalam perusahaan ataupun instansi Pemerintah dan swasta.

Kinerja karyawan yang maksimal dalam setiap perusahaan-perusahaan merupakan hasil kerja yang didamba baik secara individu maupun secara kolektif sebagai hasil dari tugas-tugas yang dibebankan kepadanya. Penilaian hasil dari kinerja karyawan biasanya dapat terlihat dari kualitas dan kuantitas output serta kemahirannya dalam melaksanakan tugas yang diberikan. Seorang karyawan dapat bekerja dengan baik jika memiliki kinerja yang tinggi sehingga menghasilkan pekerjaan yang baik. Dengan adanya kinerja yang tinggi dari setiap karyawan, diharapkan impian dari organisasi dapat tercapai. Sebaliknya, jika karyawan tidak memiliki kinerja yang tinggi maka dapat dipastikan apa yang menjadi harapan dari organisai akan menjadi mimpi belaka.

Di sisi lain sebuah perusahaan layaknya juga sebagai sebuah organisasi meskipun anggota atau karyawan terbagung di dalamnya mempunya tujuan yang relatif sama untuk memajukan organisasi atau perusahaan, namun demikian tidak dapat dipungkiri bahwa dalam setiap organinasi maupun perusahaan akan tetap ada pengaruh bahkan ambisi pribadi ataupun kelompok tertentu di dalamnya. Sehingga adanya perbedaan kepentingan di tambah dengan adanya perbedaan latar belakang sosial budaya, pendidikan akan mudah menimbulkan salah paham, sesama karyawan hingga berselisih pendapat.

Kondisi lebih buruk dari selisih pendapat, bisa jadi akan bermuara pada konflik kerja sesama karyawan sehingga menimbulkan ketidaknyamana dan dalam bekerja di perusahaan. Di sisi lain beban kerja dan aturan dari perusahaan harus tetap dijaga dan dilaksanakan sebagai wujud 
kominten pada perusahaan sekaligus untuk mencapai tujuan perusahaan. Akibatnya karyawan akan merasa tertekan (stress) dalam menghadapi kerja selanjutnya tentu akan berdampak kinerja karyawan di perusahaan.

Kenyaman dalam bekerja atau bekerja tanpa rasa stress atau konflik kerja akan menimbulkan semangat dalam melaksakan tugas yang diberikan oleh perusahaan dan semangat dalam mentaati semua peraturan Perusahaan yang salah satunya bisa tercermin dari data kehadiran karyawan. masih banyak karyawan yang tidak Masuk kerja tanpa keterangan (Alfa), karyawan datang terlambat dan karyawan pulang cepat atau pulang sebelum waktunya setiap tahunnya cenderung meningkat. Pada tahun 2014 ada 28 kali karyawan yang Alfa, 183 kasus karyawan Datang Lambat dan pulang cepat, sehingga total kasus atau masalah dalam absensi pada tahun 2014 adalah 211. Kasus absensi ini setiap tahunnya terus bertambah dengan pertumbuhan angka pelanggaran antara $14 \%$ hingga $30 \%$ setiap tahunnya. Pada tahun 2015 ada 241 kasus pelanggaran absensi atau meningkat 14,22\%. Pada tahun 2016 terdapat 285 kasus pelanggaran absensi atau meningkat $18,26 \%$. Pada tahun 2017 terdapat 371 kasus pelanggaran absensi atau meningkat $30,18 \%$ dan pada tahun 2018 terdapat 436 kasus pelanggaran absensi atau meningkat $17,52 \%$ dari tahun sebelumnya.

Hasil observasi pada survey awal yang Penulis dengan beberapa karyawan CV. Apotik Keluarga Pekanbaru ada 6 (enam) dari 10 (sepuluh) orang Karyawan menyebutkan bahwa penyebab rendahnya kinerja karyawan disebabkan adanya konflik dan Stres kerja dilingkungan CV. Apotik Keluarga. Hal tersebut terindikasikan dengan muncul beberapa faktor yang menyebabkan konflik kerja da stress kerja di antara Karyawan CV. Apotik Keluarga, salah satunya adalah cukup banyaknya beban kerja yang dirasakan oleh sebagian Karyawan. Adapun beban kerja sebagai aktifitas rutin yang harus dilakukan setiap karyawan di CV. Apotik Keluarga adalah sebagai berikut:

Eko dan Bisnis (Riau Economics and Business Reviewe) Volume 11, Nomor 3, 27 September 2020
Tabel 1 : Daftar Beban Kerja Rutin Karyawan CV. Apotik Keluarga

\begin{tabular}{|c|c|c|c|c|}
\hline No & $\begin{array}{l}\text { Nama Kegiatan/Beban } \\
\text { Kerja }\end{array}$ & Intensitas & Waktu & Keterangan \\
\hline 1 & $\begin{array}{l}\text { Membuka apotik bagi Sift } \\
\text { pagi }\end{array}$ & 1 & hari & \\
\hline 2 & $\begin{array}{l}\text { Membersihkan/Menyapu } \\
\text { dan mengepel lantai }\end{array}$ & 1 & hari & \\
\hline 3 & $\begin{array}{l}\text { Membersihkan etalase dan } \\
\text { pajangan produk }\end{array}$ & 1 & hari & \\
\hline 4 & $\begin{array}{l}\text { Membersihkan Produk } \\
\text { yang terpajang dan dalam } \\
\text { etalase }\end{array}$ & 1 & hari & \\
\hline 5 & $\begin{array}{l}\text { Memeriksa catatan } \\
\text { penjualan kemaren atau sift } \\
\text { sebelum }\end{array}$ & 1 & hari & \\
\hline 6 & $\begin{array}{l}\text { Melaksanakan Stok } \\
\text { Opname dan dikonfirm } \\
\text { dengan catatan sift } \\
\text { sebelumnya }\end{array}$ & 1 & hari & \\
\hline 7 & $\begin{array}{l}\text { Melakukan pemesan } \\
\text { obat/produk yang sudah } \\
\text { pada batas minimal stok }\end{array}$ & 3 & Pekan & Situasional \\
\hline 8 & $\begin{array}{l}\text { Mencatat setiap penjualan } \\
\text { dan Pembayaran }\end{array}$ & 1 & hari & \\
\hline 9 & $\begin{array}{l}\text { Memeriksa tanggal } \\
\text { kadaluarsa obat }\end{array}$ & 1 & hari & \\
\hline 10 & $\begin{array}{l}\text { Menarik/menyimpan obat } \\
\text { kadaluarsa dan membuat } \\
\text { laporannya }\end{array}$ & 1 & hari & \\
\hline 11 & $\begin{array}{l}\text { Melakukan penukaran obar } \\
\text { Kadaluarsa pada Produksen } \\
\text { yg mempunya garansi } \\
\text { penggantian Produk }\end{array}$ & 1 & bulan & Situasional \\
\hline 12 & $\begin{array}{l}\text { Melaporkan penjualan } \\
\text { harian/Pekan dan Bulanan }\end{array}$ & 1 & hari & Kasir \\
\hline 13 & Menutup Apotik & 1 & hari & Sift Malam \\
\hline 14 & $\begin{array}{l}\text { Menyusun dan meletakkan } \\
\text { semua perlengkapan kerja } \\
\text { secara rapi }\end{array}$ & 1 & hari & Sift Malam \\
\hline 15 & $\begin{array}{l}\text { Memasukkan kendaraan } \\
\text { operasional ke dalam } \\
\text { garage }\end{array}$ & 1 & hari & Sift Malam \\
\hline
\end{tabular}

Sumber: CV. Apotik Keluarga Pekanbaru, 2018

Dari table di atas terlihat bahwa setidaknya ada 15 tugas rutin harian yang harus dikerjakan oleh setiap karyawan (kecuali terkait laporan keuangan), sehingga banyak beban kerja yang dilakukan setiap hari tersebut bisa mengindi- kasikan terjadinya stress pada karyawan CV. Apotik Keluarga dan tentu selanjutnya akan mempengaruhi pada kinerja karyawan itu sendiri.

Faktor lain yang menjadi penyebab pasang surutnya kinerja pada CV. Apotik Keluarga Pekanbaru adalah muncul karena komunikasi sesama karyawan yang tidak berjalan dengan lancar sehingga sering menimbulkan kesalahpahaman, rasa iri hati sesama Karyawan dan rasa tidak suka antar Karyawan juga menjadi masalah yang belum mendapatkan perhatian khusus oleh Pimpinan. Penanganan konflik dilingkungan karyawan yang tidak tepat dan bijaksana dapat berimbas pada suasana dan kenyamanan kerja. Hal tersebut tidak berhenti pada situasi itu saja tetapi dapat

P.ISSN: 1410-7988 E.ISSN: 2614-123X 
berlanjut menjadi sebuah beban pada karyawan itu sendiri. Kemampuan karyawan dalam menghadapi konflik/ tekanan tentu saja tidak sama, hal ini akan sangat berbahaya bagi karyawan yang memiliki daya tahan terhadap masalah/tekanan yang rendah, karena mereka dalam keadaan suasana serba salah sehingga mengalami tekanan jiwa (stress) selanjutnya akan bermuara pada terganggunya capaian kerja atau kinerja karyawan.

\section{TINJAUAN PUSTAKA}

\section{Pengertian Menejemen Sumber Daya Manusia}

Manajemen adalah ilmu dan seni mengatur proses pemanfaatan sumber daya manusia dan sumber-sumber daya lainnya secara efektif dan efisien untuk mencapai suatu tujuan tertentu. Manajemen ini terdiri dari enam unsur (6M) yaitu: man, money, methode, materials, machines, dan market. Unsur man (manusia) ini berkembang menjadi suatu bidang ilmu manajemen disebut manajemen sumber daya manusia atau disingkat dengan Manajemen Sumber Daya Manusia yang merupakan terjemahan dari man power management. Manajemen yang mengatur unsur manusia ini ada yang menyebutnya manajemen kepegawaian atau manajemen personalia (Malayu Hasibuan, 2017:9).

Menurut Veithzal Rivai dan Deddy (2011:1), manajemen sumber daya manusia merupakan salah satu bidang dari manajemen umum yang meliputi segi-segi perencanaan, pengorganisasian, pelaksanaan dan pelaksanaan. Sedangkan Menurut Achmad Sobirin (2012) "manajemen sumber daya manusia adalah penarikan, seleksi, pengembangan, pemeliharaan, dan penggunaan sumber daya manusia untuk mencapai baik tujuan-tujuan individu maupun organisasi."

Berdasarkan pendapat dari para ahli diatas, maka dapat diambil suatu kesimpulan bahwa, fokus kajian Manajemen Sumber Daya Manusia adalah masalah tenaga kerja manusia yang diatur menurut urutan fungsifungsinya, agar efektif dan efisien dalam mewujudkan tujuan perusahaan, karyawan, dan masyarakat. Karyawan adalah perencana, pelaku, dan selalu berperan aktif dalam setiap aktivitas perusahaan

\section{Pengertian Konflik Kerja}

Ada beberapa pengertian konflik menurut para ahli manajemen antara lain: menurut Wirawan (2010:5) konflik adalah proses pertentangan yang diekspresikan diantara dua pihak atau lebih yang saling tergantung mengenai objek konflik, menggunakan pola pikir dan interaksi yang menghasilkan keluaran konflik.

$$
\text { Veithzal dan Ella (2011:999) }
$$

mengatakan konflik kerja adalah ketidaksesuaian antara dua atau lebih anggota-anggota atau kelompok (dalam suatu organisasi/perusahaan) yang harus membagi sumber daya yang terbatas atau kegiatan-kegiatan kerja dan atau karena kenyataan bahwa mereka mempunyai perbedaan status, tujuan, nilai atau persepsi.

Sedangkan menurut Melayu Hasibuan (2017:199) pengertian konflik adalah persaingan yang kurang sehat berdasarkan ambisi dan sikap emosional dalam memperoleh kemenangan. Konflik akan menimbulkan ketegangan, konfrontasi, perkelahian, dan frustasi jika tidak dapat diselesaikan.

Berdasarkan pendapat dari para ahli diatas dapat disimpulkan bahwa konflik adalah proses pertentangan yang diekspresikan diantara dua pihak atau lebih yang saling tergantung sehingga menyebabkan adanya persaingan yang kurang sehat berdasarkan ambisi, sikap emosional, perbedaan status, tujuan, nilai atau persepsi serta ketidaksesuaian antara tujuan dan peluang untuk mencampuri usaha pencapaian tujuan pihak lain dalam memperoleh kemenangan.

\section{Indikator Konflik Kerja}

Dalam penelitian ini yang dibahas adalah konflik yang berdampak negatif bagi pengembangan organisasi. Adapun indikator konflik yang berdampak negatif

P.ISSN: 1410-7988 E.ISSN: 2614-123X 
adalah sebagai berikut (Ade Florents dalam Sofi, 2013:25):

1) Tidak lagi sejalan antar seseorang dengan orang lain atau kelompok dengan kelompok lain untuk menuju tujuan perusahaan.

2) Menurunnya kinerja karyawan.

3) Menghambat tumbuh kembang kerjasama dalam perusaahaan.

4) Terhambat/terhalangi kerjasama antar individu.

5) Terganggunya saluran komunikasi antar karyawan

\section{Pengertian Stress Kerja}

Morgan \& King dalam Dhania (2010 : 16), Stress merupakan suatu kondisi internal yang terjadi dengan ditandai gangguan fisik, lingkungan, dan situasi sosial yang berpotensi pada kondisi yang tidak baik. Handoko (2011:200) mengatakan bahwa stresss adalah satu kondisi ketegangan yang mempengaruhi emosi, proses berfikir dan kondisi seseorang.

Rue dan Byars dalam Ikhwan (2013

: 5) mengemukakan "Stress is the mental and or physical condition that result fro a perceived thereat of danger (physical or emotional) and the pressure to remove it ". Artinya kondisi fisik atau mental yang dihasilkan dari perasaan akan adanya ancaman bahaya (secara fisik atau emosional) dan tekanan untuk menghilangkan bahaya atau ancaman tersebut. Maka akan timbul kecemasan yang sangat mengganggu. Stress tidak selalu merupakan fenomena yang merusak/merugikan karena dalam kenyataannya, walaupun stresss lazimnya dibahas dengan konteks negatif, namun stress merupakan suatu hal penting dalam proses yang mungkin dilalui seseorang dalam rangka mencapai tujuan. Bila digunakan untuk menggambarkan perasaan subyektif, stress merupakan persamaan dari ketegangan, kecemasan, kekhawatiran atau ketakutan. Stress dapat dilihat dari dua sisi yaitu sisi positif dan sisi negatif. Stress merupakan peluang bila itu memuaskan perolehan yang potensial dan menimbulkan keinginan- keinginan untuk melakukan hal-hal yang lebih baik.

\section{Indikator Stress Kerja}

Menurut Sinambela (2016 : 391) dari fakta yang ada menunjukkan bahwa ada beberapa pekerjaan yang teridentifikasi memiliki tingkat stresss yang lebih dibandingkan dengan pekerjaan lain. Untuk itu setiap harus bertanggung jawab untuk mengenali gejala (indikasi) perilaku ataupun keadaan karyawan yang mengalami stresss agar segera ditindaklajuti oleh tenaga kesehatan profesional. Tanda-tanda atau indikator tersebut adalah :

1. Mudah marah

2. Pelupa

3. Isolasi sosial

4. Perubahan penampilan : seperti berpakaian tidak rapi atau menurunnya berat badan

5. Perubahan sifat, menjadi sangat tertutup atau sebaliknya menjadi hiper aktif

Kadang kita tidak menyadari bahwa kita mengalami stress, kita merasa takut, atau sakit kepala bahkan gelisah, ini adalah tanda-tanda stress ringan. Sedangkan stress berat bisa mengakibatkan hilangnya kesadaran. Berbagai macam tantangan kehidupan yang dihadapi oleh individu menyebabkan tekanan-tekanan hidup baik fisik maupun emosional, begitu pula orangorang yang berprofesi sebagai pegawai. Kegiatan-kegiatan dan beban kerja yang setiap hari dilakukan merupakan satu diantara tantangan kehidupan. Beberapa kesulitan yang terjadi mempengaruhi kinerja pegawai yang mampu mengakibatkan terjadinya stresss pada pegawai itu sendiri, karena harus menghadapi masalah dan menyelesaikan dengan seluruh upaya, tenaga dan pikiran.

Dalam penelitian ini Peneliti mengembangkan kuisioner berdasarkan indikator yang diungkapkan oleh Sinambela (2016) 


\section{Kinerja Karyawan}

Pada suatu individu, kelompok, maupun organisasi diperlukan suatu penilaian untuk mengetahui tujuan akhir yang ingin dicapainya atau sering disebut dengan kinerja. Penilaian kinerja ini sangat penting dilakukan karena hal ini dapat digunakan sebagai ukuran keberhasilan organisasi dalam mencapai misinya. Selain itu, kinerja dapat digunakan untuk mengukur tingkat prestasi atau kebijakan individu maupun kelompok individu.

Menurut Veithzal Rivai dan Ella Jauvani, (2011:548) kinerja merupakan perilaku nyata yang ditampilkan setiap orang sebagai prestasi kerja yang dihasilkan oleh karyawan sesuai dengan peranannya dalam perusahaan. Sedangkan menurut Prawirosentono dalam Edy Sutrisno (2010:170) kinerja adalah hasil kerja yang dicapai seseorang atau sekelompok orang dalam suatu organisasi, sesuai dengan wewenang dan tanggungjawab masingmasing, dalam rangka upaya mencapai tujuan organisasi bersangkutan secara legal, tidak melanggar hukum, dan sesuai dengan moral maupun etika.

Dari beberapa pendapat di atas, maka dapat dikatakan bahwa kinerja adalah gambaran mengenai pencapaian Kerja pegawai atau kelompok dalam suatu organisasi dalam pelaksanaan kegiatan, program, kebijaksanaan guna mewujudkan visi, misi, dan tujuan organisasi yang telah ditetapkan sebelumnya.

\section{Indikator Kinerja Karyawan}

Menurut Robert L. Mathis dan John H. Jackson (2013:378) mengemukakan bahwa indikator kinerja yaitu:

a. Kualitas, Yaitu meliputi; ketaatan dalam prosedur, disiplin, dedikasi. Tingkat dimana hasil aktivitas yang dikehendaki mendekati sempurna dalam arti menyesuaikan beberapa cara ideal dari penampilan aktivitas, maupun memenuhi tujuan-tujuan yang diharapkan dari suatu aktivitas.

b. Kuantitas, Kuantitas merupakan jumlah yang dihasilkan dinyatakan dalam istilah

Eko dan Bisnis (Riau Economics and Business Reviewe) Volume 11, Nomor 3, 27 September 2020 seperti jumlah unit, jumlah siklus aktivitas yang diselesaikan. Kuantitas yang diukur dari persepsi pegawai terhadap jumlah aktivitas yang ditugaskan beserta hasilnya.

c. Kehandalan, Adalah kemampuan untuk melakukan pekerjaan yang disyaratkan dengan supervisi minimum. Pendapat lain menyebutkan bahwa kehandalan mencakup konsistensi kinerja dan kehandalan dalam pelayanan; akurat, benar dan tepat.

d. Kehadiran, Kehadiran adalah keyakinan akan masuk kerja setiap hari dan sesuai dengan jam kerja.

e. Kemampuan kerja sama, Adalah kemampuan seorang tenaga kerja untuk bekerja bersama dengan orang lain dalam menyelesaikan suatu tugas dan pekerjaan yang telah ditetapkan sehingga mencapai daya guna dan hasil guna yang sebesar-besarnya

\section{Pengaruh Konflik Kerja Terhadap Kinerja Karyawan}

Konflik dan stresss adalah dua hal yang beriringan dalam perilaku organisasi. Keduanya memiliki pengaruh yang baik atau positif dan juga pengaruh buruk atau negatif terhadap kinerja pegawai. Dan keduanya merupakan perkara yang tidak bisa dihindari dalam dinamika organisasi. Seperti yang disampaikan oleh Davis dan Newstrom dalam Veithzal dan Deddy (2011:312) salah satu penyebab stress kerja adalah konflik peran. Terdapat dua tipe umum konflik peran, yaitu :

a. Konflik peran intersender, dimana pegawai berhadapan dengan harapan organisasi terhadapnya yang tidak konsisten dan tidak sesuai.

b. Konflik peran intrasender, konflik peran ini kebanyakan terjadi pada karyawan dan manager yang menduduki dua jabatan di dua struktur. Akibatnya, jika masing-masing struktur memprioritaskan pekerjaan yang tidak sama maka akan berdampak pada karyawan dan manager yang berada pada posisi di bawahnya, terutama jika

P.ISSN: 1410-7988 E.ISSN: 2614-123X 
mereka harus memilih salah satu alternatif.

\section{METODE}

\section{Lokasi Penelitian}

Penelitian ini dilaksanakan pada CV. Apotik Keluarga yang berjumlah 7 gerai apotik dan tersebar di beberapa tepat di kota Pekanbaru. Adapun kantor pusat berada di apotik Keluarga Satu Jl. HR. Subrantas No.297A Kota Pekanbaru atau tepatnya bersebelahan dengan gedung Ramayana (Panam Square) Pekanbaru.

\section{Jenis dan Sumber Data Data Primer}

Data primer adalah data yang diperoleh secara langsung dari sumber asli yaitu diperoleh dari pegawai atau karyawan melalui kuesioner.

\section{Data Sekunder}

Data sekunder adalah sumber data penelitian secara tidak langsung melalui media perantara dan sudah diolah. Data ini diambil dari data-data yang telah dimiliki oleh pihak terkait, seperti sejarah perusahaan, lokasi, dan data-data yang mendukung lainnya

\section{Populasi}

Menurut Sugiyono (2014:81) Populasi adalah wilayah generalisasi yang terdiri dari objek atau subjek yang menjadi kuantitas dan karakteristik tertentu yang ditetapkan oleh peneliti untuk dipelajari dan kemudian ditarik kesimpulannya. Populasi dalam penelitian ini adalah seluruh karyawan yang ada pada Pegawai Apotik Keluarga Pekanbaru yaitu sebanyak 66 orang.

\section{Sampel}

Sampel adalah bagian dari jumlah dan karakteristik yang dimiliki oleh populasi tersebut (Sugiyono, 2014:81), selanjutnya untuk menentukan jumlah sampel, penulis berpedoman pada pendapat Sugiyono (2014:85) dengan menggunakan "sampling jenuh" yaitu teknik penentuan sampel bila semua anggota populasi dijadikan sebagai sampel. Hal ini dilakukan bila jumlah Volume 11, Nomor 3, 27 September 2020 populasi relatif kecil, atau penelitian yang ingin membuat generalisasi dengan kesalahan yang sangat kecil. Istilah lain sampel jenuh adalah sensus, dimana semua anggota populasi dijadikan sampel. Berdasarkan pendapat tersebut, maka jumlah sampel dalam penelitian ini adalah berjumlah 66 orang dikarenakan peneliti tidak diikutkan menjadi sampel.

\section{Analisis Data}

Teknik analisa yang digunakan adalah teknik analisa deskriptif dan kuantitatif. Teknik deskriptif adalah suatu analisis dengan cara mengelompokkan data yang sedemikian rupa, kemudian menghubungkannya dengan teori-teori yang berkaitan dengan permasalahan yang dihadapi oleh perusahaan sehingga dapat diambil suatu kesimpulan, sedangkan teknik kuantitatif adalah metode penelitian yang kemudian diubah dan dianalisa untuk diambil kesimpulannya menurut (Suharismi Arikunto, 2010 : 282).

\section{HASIL \\ Metode Deskriptif}

Berdasarkan hasil rekapitulasi jawaban responden terhadap pernyataan indikator variabel Konflik Kerja, diperoleh jumlah Total skor rata-rata 3,00 hal menyatakan bahwa tingkat konflik kerja di lingkungan CV. Apotik Keluarga berada pada interval Sedang, demikian pula dengan Rekapitulasi responden terhadap pernyataan indikator variabel Stress Kerja diperoleh jumlah Total skor rata-rata 3,02, hal menyatakan bahwa tingkat Stress kerja di lingkungan CV. Apotik Keluarga berada pada interval Sedang.

\section{Metode Kuantitatif \\ Uji Regeresi Linier Berganda}

Analisis ini digunakan untuk mengetahui pengaruh variabel bebas (Perilaku Konflik Kerja dan Stress Kerja) terhadap variabel terikat (Kinerja Karyawan). Persamaan dalam analisis regresi linier berganda dalam penelitian ini adalah $: \quad \mathbf{Y}=\mathbf{a}+\mathbf{B} 1 \mathbf{X} 1+\mathbf{B} 2 \mathbf{X}_{2}+\mathbf{e}$.

$$
\text { P.ISSN: 1410-7988 E.ISSN: 2614-123X }
$$


Adapun hasil Regresi Linier berganda olahan SPSS penelitian ini adalah sebagaimana table berikut :

Tabel 2 Analisis Regresi Linier Berganda

\begin{tabular}{|c|c|c|c|c|c|c|c|c|}
\hline & \multirow{2}{*}{ Model } & \multicolumn{2}{|c|}{$\begin{array}{c}\text { Unstandardized } \\
\text { Coefficients }\end{array}$} & \multirow{2}{*}{\begin{tabular}{|c|}
$\begin{array}{c}\text { Standardized } \\
\text { Coefficients }\end{array}$ \\
Beta \\
\end{tabular}} & \multirow[b]{2}{*}{ t } & \multirow[b]{2}{*}{ Sig. } & \multicolumn{2}{|c|}{$\begin{array}{c}\text { Collinearity } \\
\text { Statistics }\end{array}$} \\
\hline & & $\mathrm{B}$ & Std. Error & & & & Tolerance & VIF \\
\hline \multirow[t]{3}{*}{1} & (Constant) & 61.499 & 3.164 & & 19.437 & .000 & & \\
\hline & Konflik Kerja & -600 & .273 & -632 & -2.196 & .032 & .113 & 8.873 \\
\hline & Stress Kerja & -.010 & .304 & -.010 & -.033 & .974 & .113 & 8.873 \\
\hline
\end{tabular}

Sumber : Hasil Olahan Data Spss

Berdasarkan Tabel 2 tersebut dapat diketahui persamaan regresi linier sederhana yang dihasilkan adalah sebagai berikut :

Persamaan Regresi Linier Berganda $: \mathbf{Y}=\mathbf{a}$ $+\mathrm{B}_{1} \mathrm{X} 1+\mathrm{B} 2 \mathrm{X} 2+\mathrm{e}$

$\mathbf{Y}=61.499+(-0,600) \mathrm{X}_{1}+(-0.010) \mathrm{X}_{2}+\mathrm{e}$

a. Nilai konstanta (a) diperoleh sebesar 61.499, artinya adalah apabila Konflik Kerja (X1), dan Stress Kerja (X2) pada Variabel Kinerja Karyawan diasumsikan bernilai nol (0) atau diabaikan, maka nilai Variabel Kinerja Karyawan adalah sebesar 61.499 satuan

b. Nilai koefisien regresi $\mathbf{B} 1 \mathbf{X} \mathbf{1}=-0,600$ menyatakan bahwa jika Konflik Kerja mengalami peningkatan 1 satuan, maka akan mempengaruhi Kinerja Karyawan akan menurun sebesar $-0,600$ satuan dengan ketentuan Stress Kerja (X2) tetap NOL

c. Nilai koefisien regresi $\mathbf{B X 2}=-0.010$ menyatakan bahwa jika Stress Kerja mengalami peningkatan 1 satuan, maka akan mempengaruhi Kinerja Karyawan menurun sebesar -0.010 satuan dengan ketentuan Konflik Kerja (X1), tetap NOL.

d. Standar error (e) merupakan variabel acak dan mempunyai distribusi probabilitas yang mewakili semua faktor yang mempunyai pengaruh terhadap $\mathrm{Y}$ tetapi tidak dimasukan dalam persamaan Penelitian ini.

\section{Uji Hipotesis}

\section{Uji t}

Dengan membandingkan $\mathrm{t}$ hitung dan $\mathrm{t}$ tabel diketahui bahwa $\mathrm{t}_{\text {hitung }}>\mathrm{t}$ tabel $(2.196>$ 1,998) tanda negatif pada nilai $t$ hitung menunjukkan semakin tinggi konflik kerja

Eko dan Bisnis (Riau Economics and Business Reviewe) Volume 11, Nomor 3, 27 September 2020 akan semakin menurunkan kinerja karyawan. Nilai signifikansi Probabilitas = $(0,032)<0,05$, artinya berpengaruh secara signifikan. Maka Sesuai dengan hipotesis yang telah Penulis ajukan untuk variabel Konflik Kerja secara parsial berpengaruh negatif dan signifikan terhadap Kinerja Karyawan CV. Apotik Keluarga Pekanbaru. Dengan membandingkan $\mathrm{t}$ hitung dan $\mathrm{t}$ tabel diketahui bahwa $\mathrm{t}$ hitung $<\mathrm{t}$ tabel $(-0.033<-$ 1,998) dan probabilitas $(0,974)>0,05$. Maka untuk variabel Stress Kerja secara parsial tidak berpengaruh dan tidak signifikan terhadap Kinerja Karyawan CV. Apotik Keluarga Pekanbaru. Nilai $t$ hitung dengan tanda negatif menunjukkan semakin tinggi Stress kerja akan semakin menurunkan kinerja karyawan. Hasil ini berbeda dengan hipotesis Peneliti di awal Penelitian.

\section{Uji F}

Dengan membandingkan Fhitung dan Ftabel diketahui bahwa Fhitung $>$ Ftabel $(22.010>3,14)$ dan nilai probabilitas sebesar 0,000 $<0,05$ maka variabel Konflik Kerja (X1) dan Stress Kerja (X2) secara bersama-sama atau serentak berpengaruh signifikan terhadap Kinerja Karyawan (Y) CV. Apotik Keluarga Pekanbaru

\section{Koefisien Determinasi $\left(\mathbf{R}^{\mathbf{2}}\right)$}

Koefesien determinasi merupakan besarnya kontribusi variabel bebas terhadap variabel terikatnya. Semakin tinggi koefisien determinasi, semakin tinggi kemampuan variabel bebas dalam menjelaskan variasi perubahan pada variabel terikatnya

Tabel 3 Koefisien Determinasi

\begin{tabular}{|c|c|c|c|c|}
\hline Model & R & R Square & Adjusted R Square & Std. Error of the Estimate \\
\hline 1 & $644^{\text {a }}$ & 411 & .393 & 3.27012 \\
\hline a. Predictors: (Constant), Stress Kerja, Konflik Kerja \\
b. DependentVariable: Kinerja Karyawan \\
Sumber Olahan Data Spss
\end{tabular}

Dari tabel 3 di atas dapat diketahui nilai Adjusted $R$ Square sebesar 0,393 atau 39,3\% berarti Konflik Kerja (X1), dan Stress Kerja (X2), memberikan pengaruh terhadap Kinerja Karyawan (Y) CV. Apotik

P.ISSN: 1410-7988 E.ISSN: 2614-123X 
Keluarga Pekanbaru sebesar 39,3\% \% dan sisanya $60,7 \%$ lainnya dipengaruhi oleh variabel lain yang tidak termasuk dalam penelitian ini

\section{SIMPULAN}

Berdasarkan hasil analisis data dan pembahasan yang telah diuraikan pada bab sebelumnya, maka hasil penelitan tentang pengaruh konflik kerja dan stres kerja terhadap kinerja karyawan CV. Apotik Keluarga, maka dapat ditarik kesimpulan sebagai berikut :

1. Berdasarkan hasil rekapitulasi jawaban responden terhadap pernyataan indikator variabel Konflik Kerja, diperoleh jumlah Total skor rata-rata 3,00 hal menyatakan bahwa tingkat konflik kerja di lingkungan CV. Apotik Keluarga berada pada interval Sedang, demikian pula dengan Rekapitulasi responden terhadap pernyataan indikator variabel Stress Kerja diperoleh jumlah Total skor rata-rata 3,02, hal menyatakan bahwa tingkat Stress kerja di lingkungan CV. Apotik Keluarga berada pada interval Sedang.

2. Nilai konstanta (a) diperoleh sebesar 61.499, artinya adalah apabila Konflik Kerja (X1), dan Stress Kerja (X2) pada Variabel Kinerja Karyawan diasumsikan bernilai nol (0) atau diabaikan, maka nilai Variabel Kinerja Karyawan adalah sebesar 61.499 satuan. Nilai koefisien regresi $\mathbf{B 1 X 1}=\quad-0,600$ menyatakan bahwa jika Konflik Kerja mengalami peningkatan 1 satuan, maka akan mempengaruhi Kinerja Karyawan menurun sebesar -0,600 satuan dengan ketentuan Stress Kerja (X2) tetap NOL. Nilai koefisien regresi $\mathbf{B X 2}=-0.010$ menyatakan bahwa jika Stress Kerja mengalami peningkatan 1 satuan, maka akan mempengaruhi Kinerja Karyawan menurun sebesar -0.010 satuan dengan ketentuan Konflik Kerja (X1), tetap NOL

3. Hasil Uji T (parsial) untuk variabel konflik kerja dengan membandingkan $t$ hitung dan $\mathrm{t}_{\text {tabel }}$ diketahui bahwa $\mathrm{t}_{\text {hitung }}>\mathrm{t}$ tabel $(-2.196>-1,998)$ tanda negatif pada

Eko dan Bisnis (Riau Economics and Business Reviewe) Volume 11, Nomor 3, 27 September 2020 nilai $\mathrm{t}$ hitung menunjukkan semakin tinggi konflik kerja akan semakin menurunkan kinerja karyawan. Nilai signifikansi Probabilitas $=(0,032)<$ 0,05 , artinya berpengaruh secara signifikan. Maka Sesuai dengan hipotesis yang telah Penulis ajukan bahwa variabel Konflik Kerja secara parsial berpengaruh negatif dan signifikan terhadap Kinerja Karyawan CV. Apotik Keluarga Pekanbaru. Adapun Uji $\mathrm{T}$ untuk variabel Stress Kerja, diketahui bahwa $\mathrm{t}_{\text {hitung }}<\mathrm{t}$ tabel ($0.033<-1,998)$ dan probabilitas $(0,974)$ $>$ 0,05. Maka untuk variabel Stress Kerja secara parsial tidak berpengaruh dan tidak signifikan terhadap Kinerja Karyawan CV. Apotik Keluarga Pekanbaru. Nilai $t$ hitung dengan tanda negatif menunjukkan semakin tinggi Stress kerja akan semakin menurunkan kinerja karyawan. Hasil ini berbeda dengan hipotesis Peneliti di awal Penelitian.

4. diketahui bahwa $\mathrm{F}_{\text {hitung }}>\mathrm{F}_{\text {tabel }}$ (22.010 > 3,14) dan nilai probabilitas sebesar $0,000<0,05$ maka variabel Konflik Kerja (X1) dan Stress Kerja (X2) secara bersama-sama atau serentak berpengaruh signifikan terhadap Kinerja Karyawan (Y) CV. Apotik Keluarga Pekanbaru

nilai Adjusted $R$ Square sebesar 0,393 atau 39,3\% berarti Konflik Kerja (X1), dan Stress Kerja (X2), memberikan pengaruh terhadap Kinerja Karyawan (Y) CV. Apotik Keluarga Pekanbaru sebesar 39,3 \% dan sisanya 60,7 \% lainnya dipengaruhi oleh variabel lain yang tidak termasuk dalam penelitian ini

\section{DAFTAR RUJUKAN}

Ali, Hasan. 2013. Marketing dan KasusKasus Pilihan. Yogyakarta. CAPS (Center For Academic Publishing Service).

Andespa, Roni. 2012. Metodologi Riset Bisnis. Pekanbaru, Al Huda Press. 
Arikunto, Suharsimi, 2010. Prosedur Penelitian Suatu Pendekatan Praktek . Jakarta. Rineke Cipta.

Ashari, Purbayu Budi Santoso. 2005. Analisis statistic dengan Microsoft exel dan SPSS. Yogyakarta.

Buchari, Alma. 2002. Manajemen Pemasaran dan Pemasaran Jasa. Bandung: Alfabeta.

Buchari, Alma. 2007. Manajemen Pemasaran dan Pemasaran Jasa. Bandung: Alfabeta.

Ghozali, Imam. 2005. Analisis Multivariate Dengan Program SPSS. Badan Penerbit Universitas Diponegoro. Semarang.

Griffin, Ricky W dan Ebert, Ronald J. 2008. Bisnis.Edisi 8 jilid 1. Jakarta: Erlangga.

Hartono, Jogiyanto. (2010). Metodologi Penelitian Bisnis: Salah Kaprah dan Pengalaman-Pengalaman. Edisi Pertama. BPFE. Yogyakarta.

Hegia Tarigan. 2014. Skripsi: Pengaruh Promosi Penjualan Terhadap Keputusan Pembelian Konsumen The Body Shop Outlet Bandung Indah Plaza,

Hermawan, Agus. 2012. Komunikasi Pemasaran. Jakarta:Erlangga.

Hermawan, Asep. 2013. Penelitian Bisnis. Universitas Trisakti, Jakarta.

Kotler, Philip. 2005. Manajemen Pemasaran. Jilid I, PT. Indeks Kelompok Gramedia, Jakarta.

Kotler, Philip \& Gary Amstrong. 2004. Dasar-dasar Pemasaran. Edisi 9 Jilid I, dialihbahasakan oleh Alexander Sindoro, Jakarta: Indeks.

Kotler, Philip \& Gary Amstrong. 2006. Principles of Marketing. New Jersey: Pearson International Edition.

Kotler, Philip \& Gary Amstrong. 2008. Prinsip-prinsip Pemasaran. Edisi 12. Jilid 1. Jakarta: Erlangga.

Kotler, Philip \& Kevin Lane Keller. 2009. Manajemen Pemasaran Edisi 13 Jilid 1. Penerbit Erlangga: Jakarta.

Eko dan Bisnis (Riau Economics and Business Reviewe) Volume 11, Nomor 3, 27 September 2020
Kotler, Philip \& Keller, Kevin Lane. 2012. Marketing Management 14th Edition.New Jersey: Pearson Education,Inc.

Kotler, Philip \& Kevin Lane Keller, 2007. Manajemen Pemasaran. Jilid I. Edisi Kedua belas. PT. Indeks, Jakarta.

Kotler, Philip \& Kevin Lane Keller, 2008. Manajemen Pemasaran. Jilid I. Penerbit Erlangga: Jakarta.

Martono, Nanang. 2012. Metode Penelitian Kuantitatif Analisis Isi dan Analisis Data Sekunder. Jakarta : PT. Raja Grafindo Persada.

Mowen, Jhon C \& Michel Minor. 2009. Perilaku Konsumen. Edisi Kelima Jilid I.

Nengsih. 2011. Skripsi: Pengaruh Promosi Penjualan Terhadap Keputusan Menginap Di Hotel Kedaton Bandung.

Rambat, Lupiyoadi, \& A. Hamdani. 2006. Manajemen Pemasaran Jasa. Edisi Kedua. Jakarta: Salemba Empat.

Rinaldo Putra. 2015. Skripsi : Pengaruh Promosi Penjualan Terhadap Keputusan Pembelian Mebel Pada CV. Lautan Rezeki Pekanbaru.

Sangadji dan Sopiah. 2013. Perilaku Konsumen. Penerbit Andi. Yogyakarta.

Saputra, Hendra. 2008. Analisis Pengaruh Strategi Bauran Pemasaran Terhadap Keputusan Pembelian di Kota Medan. Universitas Sumatera Utara.

Sudarmanto R. G., 2005, Analisis Regresi Linier Ganda dengan SPSS, Edisi Pertama, Penerbit Graha Ilmu, Yogyakarta.

Sugiyono, (2008). Metode Penelitian Kunatitatif Kualitatif dan R\&D. Bandung Alfabeta.

Sugiyono. 2013. Metode Penelitian Pendidikan Pendekatan

Kuantitatif, Kualitatif, dan R\&D. Bandung: Alfabeta.

Sumarwan, Ujang. 2004. Perilaku Konsumen Teori dan Penerapannya dalam Pemasaran. P.ISSN: 1410-7988 E.ISSN: 2614-123X 
Cetakan kedua. Ghalia Indonesia.

Bogor Selatan.

Supranto, J. 2009. Statistik Teori Dan Aplikasi. Edisi Ketujuh. Jilid 2. Erlangga. Jakarta.

Sutisna 2003. Perilaku Konsumen dan Komunikasi Pemasaran. Rosda Karya, Bandung.

Tjiptono, Fandy. 2008. Strategi Pemasaran. Edisi 3. Andi: Yogyakarta.

Zulaicha, Santri \& Irawati, Rusda. 2016. Pengaruh Produk Dan Harga Terhadap Keputusan Pembelian Konsumen Di Morning Bakery Batam 